\title{
The business management of the village government in managing Village Owned Enterprise
}

\section{Manajemen bisnis pemerintah desa dalam pengelolaan Badan Usaha Milik Desa}

\author{
Nikki Prafitri, Paulus Israwan Setyoko, \& Dyah Retna Puspita \\ Master of Public Administration, Universitas Jenderal Soedirman \\ Address: Jalan HR. Bunyamin 708, Grendeng Purwokerto Utara, Central Java 53122 \\ E-mail: prafitrinikki@gmail.com
}

\begin{abstract}
Local Government business management through a Village Owned Enterprise is a new public management application. The Village government's business is carried out by applying business techniques, values and principles. The purpose of the Village Owned Enterprise is to increase the village's original income and economy. The differences involved in the success of the Village-Owned Enterprise management is triggered by differences in the application of government business principles, consisting of several aspects including the business plan, capital, accountability, transparency, reporting, corporate accounting and the payroll system. This research focused on the application of government business principles in relation to the management of the Village Owned Enterprise. The research used a qualitative research method and interactive data analysis method. Furthermore, the research was conducted in two villages; Serang Village, Karangreja Subdistrict, Purbalingga Regency and Pernasidi Village, Cilongok Subdistrict, Banyumas Regency. The research findings showed that the involvement of the village head in the preparation and socialisation of the business plan, the delegation of authority in relation to capital, the commitment to implementing transparency, the control over the officer's accountability and reporting, audits on accounting and the participation and cooperation from various stakeholders to motivate the officers in managing Village-Owned Enterprise for village welfare. The listed are the preconditions of village government business management through the Village-Owned Enterprise. Based on the finding of the phenomenon in the field regarding village business management through the Village Owned Enterprise, there are several recommendations to strengthen the management of the economic institution itself.
\end{abstract}

Keywords: business principles; government business; new public management; village-owned enterprise

\begin{abstract}
Abstrak
Manajemen bisnis pemerintah desa melalui BUM Desa merupakan cerminan dari penerapan paradigma New Public Management. Bisnis pemerintah desa dilakukan dengan menerapkan teknik, nilai dan prinsip bisnis. Tujuan dari BUM Desa adalah meningkatkan pendapatan asli desa dan perekonomian desa. Perbedaan keberhasilan pengelolaan BUM Desa dipicu oleh perbedaan penerapan prinsip-prinsip bisnis pemerintah yang terdiri dari aspek business plan, permodalan, akuntabilitas, transparansi, pelaporan, akuntansi perusahaan dan sistem penggajian. Penelitian ini terfokus pada penerapan prinsip-prinsip bisnis pemerintah dalam pengelolaan BUM Desa. Metode penelitian yang digunakan dalam penelitian ini adalah metode penelitian kualitatif. Penelitian ini dilakukan pada BUM Desa di Desa Serang, Kecamatan Karangreja, Kabupaten Purbalingga dan Desa Pernasidi, Kecamatan Cilongok, Kabupaten Banyumas. Metode analisis data yang digunakan adalah model analisis interaktif. Hasil penelitian menunjukkan bahwa keterlibatan kepala desa dalam penyusunan dan sosialisasi business plan, pelimpahan wewenang dalam permodalan, komitmen untuk menerapkan transparansi, kontrol terhadap akuntabilitas pengurus dan pelaporan, audit terhadap akuntansi serta partisipasi dan kerja sama dari berbagai stakeholder untuk memotivasi pengurus dalam mengelola BUM Desa demi kesejahteraan desa merupakan prasyarat manajemen bisnis pemerintah desa melalui BUM Desa. Mengacu pada fenomena yang ada dalam mengungkapkan manajemen bisnis pemerintah desa melalui BUM Desa, maka terdapatbeberaparekomendasiuntukmemperkuatpengelolaan lembaga ekonomipedesaantersebut.
\end{abstract}

Kata kunci: Badan Usaha Milik Desa; bisnis pemerintah; manajemen publik baru; prinsip bisnis

\section{Introduction}

Local business management is an approach within the public management sector to implement business concepts, techniques, and values in the private sector (Denhart \& Denhart 2007, Hood 1991, 
Osborne 2006, Pollit 2007). In addition, the local business management is an implementation of a new public management paradigm in order to increase the economic sector as well as its efficiency and effectivity (Fatemi \& Benmanesh 2012, Philip \& Daganda 2013, Osborne \& Gaebler 1999, Appana 2011). According to Lan (2016), a government business is a business which operates itself via business activities such as the public interest-based business model within a State Owned Enterprise. This corporation has an obligation to develop capital for the sake of the public interest.

The need to conduct government business at the village level is needed, as according to Suriadi et al (2015) in his research, his findings showed that village government businesses managed, through Village Owned Enterprises, to support the strengthening of the village's income for rural development to allow them to be more independent. A Village-Owned Enterprise is a business entity in which most of its capital is owned by the village through direct participation from the village assets, which are separated in order to manage the assets, services, and other businesses in order to increase the welfare of society in the area. The objective of this kind of corporation is to increase the village's original income (PADes) and the village economy.

The previous research conducted by Vantha (2016) found that the public sector has not been able to implement privatisation, contracting out and decentralisation because it is still influenced by political culture, rampant corruption and a lack of understanding of public service providers. Furthermore, according to Lan (2016), it was found that there are deficiencies in business management through state-owned companies, namely related to the differences in management function between state and company ownership, company operating mechanisms that have not been fully permitted, pressure from the state, the monitoring of companies that are ineffective and low employee quality. In addition, Hidayati (2016) found that Village Owned Enterprise administrators are often inexperienced and did not have an educational background relevant to the work, they had unprofessional managers and so were only able to achieve a number of goals.

The Purbalingga District Government and the Banyumas Regency Government are encouraging village governments to establish and develop their own private enterprises. The most active village when it comes to business management is Serang Village, while Pernasidi Village is one of the villages that is only just beginning to establish its own enterprises. The practices of the management of Serang $B U M D e s$ and $B U M$ Desa Pernasidi have differences in terms of their organisational structure, business units and contribution to PADes. The organisational structure the Serang enterprises involve the village official officers, while Pernasidi's involves people outside of the village official officers. In terms of the managed business units, Serang enterprises have been actively running five business units such as tourism, agriculture, livestock, financial services and clean water. Meanwhile, Pernasidi Village only runs two out of five possible business units, which is the commodity market business unit and village tourism. Serang Village Enterprises have consistently contributed to PADes since 2011, while Pernasidi's has only contributed to PADes since 2014.

Compare to Pernasidi's enterprises, Serang Village Owned Enterprises are considered to be more successful in terms of their management. These conditions are caused by several problems in government business management through the Village Owned Enterprises that are not in accordance with the application of the business principles of the village government. Kurtz \& Boone (2011) emphasise business practices in relation to the aspects of corporation culture, capital, business planning, compensation, reporting, business accounting involving activities, customer-driven marketing, empowering people, business ethics and social responsibility. Emirzon (2007) argues that business activities require business arrangements and regulations through the application of good corporate governance principles. According to Fung (2014), the principles of transparency and accountability are two principles that can create good corporate governance.

The objective of this research is to analyse and to understand how to apply business principles in the management of Village Owned Enterprises to improve PADes and the village economy. The business principles that being observed are in the business plan, capital, accountability, transparency, reporting, corporate accounting and the payroll system. 


\section{Research Method}

The research was conducted in Serang Village, Karangreja District, Purbalingga Regency and Pernasidi Village, Cilongok District, Banyumas Regency. The locations were chosen because Serang Village and Pernasidi Village established Village Owned Enterprises before it was reaffirmed by the government that every village was obliged to establish their own enterprises through Law Number 6 of 2014. However, the development of the two enterprises is different regarding their existence. The Village Owned Enterprise in Serang has successfully managed the village government business, as shown through its contribution to increasing its PADes. This success is due to its effective organisational structure, which still involves the village government. As for Pernasidi Village, even though their enterprises are running properly, they still cannot offer the maximum benefits possible for the people in the village, especially in relation to increasing the villager's income. The organisational structure of the Village Owned Enterprise of Pernasidi Village never involved the local government officer in the management process. This research used the purposive sampling technique to select the informants and to collect the information. The informants in this study consisted of the village government, Village Owned Enterprise officials and the Village Owned Enterprises supervisory boards as the key informants and the community as the supporting informants. The village government consisted of the Village Head. The management of the Village Owned Enterprises included the Chairperson, Secretary, Treasurer and Head of the Business Unit. The Supervisory Board consisted of the BPD members and community leaders. The district government consists of the Village Community Empowerment Office of Purbalingga Regency and the Village Community Empowerment Office of Banyumas Regency. The community in Serang Village consists of the Head of the RW, the community who are Village Owned Enterprise investors, and farmers and traders in the tourism business unit. The community in Pernasidi village consists of the Chairperson of the RW, and traders and employees in the market business unit. The reason for choosing these informants is because the party has a direct relationship with the Village Owned Enterprises and is considered to be the most knowledgeable regarding the development of Village Owned Enterprises in each village. The research used a qualitative research method. Tis method has several approaches which tend to apply the open-ended question method, emerging approaches, textual data or images (Creswell, 2014). The focus of this research was village government businesses in the management of Village Owned Enterprises as seen from the aspects involved in the implementation of the business principles of the village government in order to improve the village economy and PADes. The data analysis method used was an interactive analysis model developed by Miles et al (2014), which consists of data collection, data condensation, data presentation, verification and the conclusion.

\section{Results and Discussion}

Government business is a form of government transformation in the public sector, committing to doing business through a management approach by applying business styles to public sector management (Hope 2012, Ibietan \& Joshua 2015). The objective of this business is to increase income through profits, which are then distributed to the government as shareholders (Osborne \& Plastrik 2000). Appana (2011) argues that the government needs to run a government business in order to improve discipline in relation to resource use, cost savings and increased work discipline. Government business management is carried out by applying business principles to the public sector, such as business plans, capital, accountability, transparency, reporting, corporate accounting and payroll systems (Kurtz \& Boone 2011, Fung 2014).

\section{Business plan}

The research findings show that the business plan used in managing the village government business through the Village Owned Enterprises was made in a simple form compared to the business plan used in the private sector. The preparation process in relation to preparing the business plan was a non-participatory method which did not involve all members of the Village Owned Enterprise board and the community. Impacts happen due to the limitations and lack of experience of the Village Owned Enterprises in managing and preparing business plans. In consequence, the Village Owned 
Enterprises in Serang Village can still survive and develop. Meanwhile, Pernasidi Village enterprises are less developed.

According to Kurtz \& Boone (2011), the business plan in the private sector focused on the formulation of a business plan consisting of an executive summary of the business being run and an introduction that includes the business, financial and marketing purposes. Wilson et al. (2015), in a previous study, found that planning needs to be carried out in a participatory manner, extended to all levels of the planning process including community involvement. Subandi (2016), in his research results, stated that the role of the village heads is needed to promote increasing community participation in rural development related to the duties and functions of influencing, directing and encouraging behaviour as well as conducting visits and guidance to work together to achieve the desired goals.

The Village Owned Enterprise will run with a simple business plan format without implementing a business plan that focuses on a detailed business format such as in the private sector and with minimal participation from the Village Owned Enterprises officials and the community. The role of the head of the village in this case is very important. The head of the village is the one who knows and understands the real condition of the village, which is why he can seize business opportunities and potential sectors in the village as they arise. In preparing a business plan, the head of the village is the one who can accommodate as well advocate the inability of the managers and administrators. He is also in charge when it comes to directing management. In addition, the head of the village should conduct socialisation regarding the business plan and management to the society concerning the Village Owned Enterprise, as well as encouraging them to be actively involved. As a consequence, a simple business plan will likely run well.

Proposition 1: Although the business plan conducted by the local government is still in a simple format and is less participatory, it is considered to be effective due to the active involvement of the head of the village in terms of the preparation and socialisation of the business plan in relation to society and the stakeholders.

\section{Capital}

The research findings show that Village Owned Enterprises have good modal access capabilities because of the involvement of the head of the village. The Serang Village Head has a broad capital access network, which can help Village Owned Enterprise managers who do not have capital access capabilities. This would allow them to get capital assistance from the central government, provincial governments, district governments, private parties and partners within the community. In contrast, Pernasidi Village Owned Enterprise has a minimum capital access capability and there is no direction from the village head, causing a lack of initiative in relation to establishing capital cooperation with other parties. The main capital source comes from the local equity capital of the village income (APBDes). In fact, the Village Owned Enterprises managed by Pernasidi Village do not involve the official officer, but only involve the local government without any legal authority. The capital cooperation is dominated by people in the government and who seek to fulfil their own interests rather than being used for the development of the market and business.

Kurtz \& Boone (2011) argue that a business or corporation needs to obtain, maintain and increase its capital to operate the business and interests, as well as the development of the corporation itself. According to Akpanuko \& Asogwa (2013), stakeholders in a business corporation are the principal, the managers and the agents at the same time. The principal delegates authority to the agent to act based on the mandate of the principal. Sugito et al. (2016), in his research results, stated that the village government determines all of its development programs and budget without providing an open opportunity for community involvement, which can produce a culture that is less democratic, less participatory, less transparent and less responsible in relation to the development process.

The ability capital and capital equity access depend on the direct involvement of the head of the village. The village head gives direction to the access to the capital network that is owned, but in 
agreement to the implementations carried out by the managers and managers of the Village Owned Enterprise. The opportunities given by the village head to the Village Owned Enterprise to manage capital cooperation through the delegation of authority can provide an opportunity for Village Owned Enterprise to learn to manage their own capital and build business partnerships. This delegation of authority also avoids the interests of the village government in association with the capital of the Village Owned Enterprise, which means that the capital obtained can be used for business development.

Preposition 2: The ability to access capital is high and the success of capital cooperation is due to the delegation of authority from the village head to the Village Owned Enterprise, and for to act in accordance with the directions of the village head.

\section{Accountability}

The research findings showed that the managers are less professional in terms of work, regarding their commitment and responsibility. However, the management and the officer maintained their job obligations, especially in Serang Village. The officer maintained their accountability in relation to contributing to their role of increasing the village income as well as paying heed to their accountability when reporting activities. In addition, the active involvement and participation of the head of the village is important concerning controlling the job performance of the employer of the Village Owned Enterprise. This is because he also make sure that each individual provides contributions and maintains reporting activities consistently. Thus, the involvement of the head of the village can overcome the weaknesses of the managers in terms of their capacity. The contribution of the Village Owned Enterprise to the village income can be seen in Table 1.

Table 1.

The business results related to the contribution of the Village Owned Enterprise in Serang Village towards the village income

\begin{tabular}{cc}
\hline Year & $\begin{array}{c}\text { The contribution to } \\
\text { the village income } \\
\text { (Rupiah) }\end{array}$ \\
\hline 2012 & 7.000 .000 \\
2013 & 10.800 .000 \\
2014 & 26.573 .750 \\
2015 & 55.453 .375 \\
2016 & 115.453 .375 \\
\hline
\end{tabular}

Source: Income and Expenditure Budget of Serang Village

The Village Owned Enterprise of Pernasidi is separated from the village government organisations. The Village Owned Enterprise managers have the authority to control and manage their management. This caused a discrepancy in the work area of the Village Owned Enterprise's management, such as the inconsistency contribution of the PADes and the neglecting of the implementation of the routine reporting activities of the Village Owned Enterprise. In consequence, the workload of the managers increased, because they do not have the compelling power to regulate the Village Owned Enterprise's management so then they are held accountable when it comes to carrying out their duties. The managers and the administrator who come from outside the circle will ignore the orders and manage to prioritise their own interest. The inactive involvement of the head of the village as the leader also play an important role in this uncontrolled situation.

The Village Owned Enterprise of Pernasidi could only accommodate real contributions toward PADes in 2014 due to the unstable income of the village. The contributions of the Village Owned Enterprise of Pernasidi can be seen in Table 2.

Fung (2014) argues that accountability is a condition where all regulations that determine the responsibilities of governance, incentives and sanctions faced by the board, management and staff 
must be well articulated. The board members must be responsible and accountable in every decision and action to ensure that managers use the company resources efficiently and put aside their personal interests. Lan (2016), in his research results, stated that one of the shortcomings in government business management that is managed through state enterprises is the ineffective monitoring and that the quality of the company's state employees is low. Hardijono et al. (2014) explained that most of the organisational structure of the Village Owned Enterprise, which is not part of the Village Owned enterprise organisational structure, is that it tends to be inefficient at providing services to villagers.

Table 2.

The business contributions of the Village Owned Enterprise in Pernasidi Village toward the village income

\begin{tabular}{ccc}
\hline Year & $\begin{array}{c}\text { PADes } \\
\text { (Rupiah) }\end{array}$ & $\begin{array}{c}\text { BUM Desa } \\
\text { Contribution } \\
\text { (Rupiah) }\end{array}$ \\
\hline 2012 & 158.428 .848 & - \\
2013 & 83.888 .828 & - \\
2014 & 70.580 .099 & 9.400 .000 \\
2015 & 102.540 .000 & - \\
2016 & 101.424 .428 & - \\
2017 & 125.198 .856 & - \\
Source: Income and Expenditure Budget of Pernasidi Village
\end{tabular}

In the Village Owned Enterprise case, the head of the village is responsible for the accountability enforcement concerning maintaining and controlling work responsibilities. The lack of capability and ability of the employees makes controlling and monitoring activities not enough to ensure their accountability. A routine control check needs to be done by the head of the village to ensure that everything is in the right place.

Proposition 3: The realisation of the management work base and the objective fulfilment of the Village Owned Enterprise as a responsibility action from the head of the village in controlling the business.

\section{Transparency}

The research findings show that the management of the Village Owned Enterprise of Serang Village provides information media platforms such as websites, social media, information centre tables, banner information and information boards for the Village Owned Enterprise developments that are ongoing. This initiative was prompted by the board as a manifestation of the head of the village's commitment to management transparency. The head of the village initiates and delivers the information regarding the corporation and makes sure that every element gets the right information. This kind of activity triggers the employee to administer the transparency value. As a consequence, it creates trust building between society and the Village Owned Enterprise, since the society has become a priority business partner and is actively involved with the business activities.

Pernasidi Village Owned Enterprise provides an easy information platform for all stakeholders in the corporation. The meetings were not held to deliver the financial information or the development of the Village Owned Enterprise to society. Due to the lack of commitment of the managers to ensure that all of the stakeholders get the information, this happens repeatedly. In addition, there is a lack of initiative and motivation in the managers when it comes to implementing the transparency principals. The head of the village also does not provide clear direction and order to the management of the Village Owned Enterprise, for them to be transparent in every activity regarding to the job ethics. As a consequence, the society has a bad perception of their local government business, especially the financial and human resource management. 
According to Fung (2014), transparency could be achieved if the company has open and fast access to the information needed by the society in order to build trust. Lumentut et al. (2017) stated, from his previous research results, that transparency is a company commitment which is characterised by an attitude or action that discloses all business material and information regarding the impacts that can influence the decisions of investors or other stakeholders. The research findings conducted by Subandi (2016) show that the heads of the villages have an important role in motivating the community, providing information relating to the development of the right community and giving examples as leaders. This will encourage the society to play an active role in rural development.

The success of the implementation of transparency is due to the strong commitment of the leader in the village to make sure that all information is disclosed, and that they encourage the managers and their staff to always provide information regarding the development of the business through regular meetings or any kind of social media platform. These activities will create trust among the stakeholders in the Village Owned Enterprises.

Proposition 4: The commitment of the village head to create easy access information through social media platforms and to ensure that the business is managed transparently.

\section{Reporting}

The research findings show that the Village Owned Enterprises in Serang Village has reported regularly since there is direct supervision by the head of the village. He checks the financial reporting system and controls the managers and staff regularly. This active involvement facilitates easier communication and a smoother coordination system, as well as the reporting activities between the head village and the Village Owned Enterprise. The corporation responds and reports on the financial and job performance positively. The head of the village becomes the central point, making sure that all of the financial reporting system and performance is manifested.

Pernasidi Village's Owned Enterprise (VOE) does not provide financial reports on the routine performance to the village head and the supervisory board, even though routine financial reports are basically made. The low control of the village head due to the waiting list report system worsens the implementation of the routine financial reporting system. The lack of transparency and openness of the managers toward the head of the village and the supervisory board is related to the low effectivity and job performance of the VOE officer. The limited control and intervention of the head of the village is due to the separation of the organisational structure between the VOE and the local government. According to Nhema (2015), privatisation requires the absence of government intervention and public control in relation to meeting any economic, financial and social objectives. Vantha (2016), in her research, found that the public sector has not been able to implement privatisation, contracting out and decentralisation because it is still influenced by the political culture, rampant corruption and lack of understanding of public service providers.

According to Kurtz \& Boone (2011), the establishment of a reporting, monitoring and auditing system is needed in order to let the people know all of the activities as well as any shortcomings or errors, so then they can report to related government institution. Doyle et al. (2007), in the results of his research, stated that companies that tend to be smaller, newer, weaker and complex actually grow faster, but have problems related to unhealthy financial problems due to the lack of internal control.

A Village Owned Enterprise that is led by a less competent and inexperienced manager or head will simultaneously have a lack of control over the employees. Thus, the control of the leader is an important thing to help the manager make sure that the financial reporting and performance checking has been done consistently.

Proposition 5: Despite the separation between the VOE and the local government, the financial reporting system as well as the performance checking is done by the head of the village. 


\section{Company Accounting}

The research findings shows that the VOE's accounting system, both in Pernasidi and Serang Village, were made in a simple way based on the abilities and the capacity of the financial reporting system department. The financial reports were made as simple as possible to facilitate the stakeholders in understanding the report. The financial statements only contain information on income, expenses and balances. However, this simple way of financing shows a monthly surplus income because of the routine audits and control by the head of the village. The VOE's cashflow is well managed and controlled by the head of the village. This is quite a contradictory with the statement of Kurtz \& Boone (2011), regarding the meaning of private sector company accounting, which is a procedure conducted by an accountant who converts individual data transactions into a financial statement called an accounting cycle. The lack of ability and inexperience of the officers has led to this kind of tangled situation. As the results of the study from Hidayati (2015) show, human resources who handle VOE have no experience and have an unrelated educational background. According to Osborne (2006), one of the key elements of the implementation of new public management is the emphasis on control and the evaluation of inputs and outputs.

The Pernasidi's VOE financial statements were compiled by the chairman and secretary for the tourism business unit and by the treasurer for the market business unit. In addition, the financial statements do not go through an inspection and audit process from the village head and the supervisory board. This kind of condition has caused a budget deficit and a lack of monitored VOE' finances.

Proposition 6: Because of the routine audits by the head of the village, the arrangement of the financial reports and statements are running quite well in spite of its simple accounting system and inexperienced workers.

\section{The Payroll System}

The research findings show that Serang Village VOE implemented a payroll system after going through a long process, because the payroll system was only implemented in 2016. The determination of the salary was decided by the village head, manager and several VOE officials who are dominated by the village apparatus. The involvement of the village head and village government caused several income inequalities in the process. The Serang Village Government Affairs get insurance which comes from the profits of the VOE. Meanwhile, the supervisory head does not receive any of the incentives based on their VOE bylaws/statute because they are considered passive. However, the payroll system continues to run smoothly without conflict, both due to the internal VOE, the supervisory board and the community.

Kurtz \& Boone (2011) argued that a salary is a company tool used to motivate employees to excel in their work. The management of Serang VOE is not oriented and motivated concerning how much profit is obtained for personal gain, but that it is gained for the welfare of the village. The community does not necessarily care if the village apparatus gets a salary that comes from their profession as the village government and VOE officials. The community has felt the impact of the existence of the VOE by participating as business partners and earning an income. A salary is not the only tool to use to motivate VOE Serang officials.

According to Stoker (2006), the power of public value management is deemed necessary to demonstrate that motivational forces do not depend on regulations or incentives driven by involvement in networks and partnerships. According to Nhema (2015), most developing countries tend to pay more attention to improving their social welfare rather than follow the guidance and decisions based on market economic principles. To manifest this goal, according to Farjad et al (2015), his research findings stated that it needed participation and cooperation with the community in various fields. Hardijono (2014) stated that the people assigned as VOE officials were not driven by a materialbased motivation, but were instead motivated and oriented based on non-material factors, such as social respect and political interest. 
The success of the VOE is supported by the implementation of public values, therefore a salary was not the only motivation that triggered them, but the cooperation and participation values between the local government, the VOE's management official, society and other stakeholders, in the context of developing their village, also helped. The village's welfare are the main reason for them to work and develop the business. Despite the inability of the Pernasidi Village to implement the payroll system for the official officers in the VOE, it is able to pay the salary of the employees who manage the tourism business unit.

The decline of the payroll system is due to the lack of commitment of the workers from outside of the village. They prefer to prioritise their personal interests for the sake of money. This phenomenon is in contrast with Hardijono's findings from his previous research. The demand for a decent percentage of salary for the VOE official workers is not in line with the development of the business and the increasing social welfare in the area. This can be seen from the lack of effort to invite the public to become business partners in the market business unit, in order to redevelop their businesses and to enliven trading activities. This unprofessional management causes less developed VOEs and a low income in the village overall.

Proposition 7: The payroll system that has been implemented is not necessarily the main reason and motivation of the people to continue running the business. There are a lot of things to take into consideration such as the achievement of village's welfare through participation and cooperation.

\section{Conclusion}

The head of the village's involvement in business plan creation and socialisation, the delegation of capital authority, the commitment to implementing transparency, the control of the officer's accountability toward reporting activities, the execution of audits in accounting and the participation and cooperation from various stakeholders to motivate the officers in managing the Village-Owned Enterprise for village welfare is a precondition of village government business management through the Village-Owned Enterprise. Based on the finding of the phenomenon in the field regarding village business management through the Village Owned Enterprise, there are several recommendations to strengthen the management of the economic institution itself. The officers of the Village Owned Enterprise should conduct meetings between the local government and the local society to discuss and review the more participative business plans and to develop common knowledge among them. The head of the village should participate in the training facilitated by formal institutions which covers business in order to strengthen the institution's capacity. The active participation of the society needs to be strengthened by the Village Owned Enterprise. Furthermore, the innovation and technological application through social media is needed in order to increase the transparency of information and promotion access. In addition, the local government needs to create a meeting forum within society to increase awareness as well as the development of the Village Owned Enterprise.

\section{References}

Appana S (2011) New public management and public enterprise restructuring in Fiji. Journal of Fiji Institute of Applied Studies1 (1):51-73.

Akpanuko EE \& Asogwa IE (2013) Accountability: A synthesis. International Journal of Finance and Accounting 2 (3):164-173.

Creswell JW (2014) Pendekatan Metode Penelitian Kualitatif, Kuantitatif dan Campuran (Edisi Keempat). Yogyakarta: Pustaka Pelajar.

Denhart JV \& Denhart RB (2007) The New Public Service: Serving, Not Steering. United States of America: M.E Sharpe.

Doyle J, Ge W, \& McVay S (2007) Determinants of weakness in internal control over financial reporting. Jurnal of Accounting and Economics 44:193-223.

Emirzon J (2007) Prinsip-Prinsip Good Corporate Governance Paradigma Baru dalam Praktik Bisnis Indonesia. Yogyakarta: Genta Press. 
Farjad HR, Daneshfard K, Mazaheri MM, \& Shirvani A(2015) The impact of new public management (NPM) and citizens public participation on public policy Iran. European Journal of Natural and Social Science 4 (1):247-254.

Fatemi M \& Benmanesh MR (2012) New public management approach and accountability. International Journal of Management, Economics and Social Sciences 1 (2):42-49.

Fung B (2014) The demand and need for transparency and disclosure in corporate governance. Universal Journal of Management 2 (2):72-80.

Hardijono R, Maryunani, Yustika Ae, \& Ananda CF (2014) Economic independence of the village through institutional village enterprises (BUMDes). IOSR Journal of Economics and Finance (IOSR-JEF) 3 (2):21-30.

Hidayati U (2015) Performance analysis of village-owned enterprise managers as a basic of designing education and training. European Journal of Business and Management7 (32):143-147.

Hood C (1991) Public management for all seasons?. Journal of Public Administration, 69:3-19.

Hope KR (2012) Managing the public sector in kenya: Reform and transformation for improved performance. Journal of Public Administration and Governanance 2 (4):128-143.

Ibietan J \& Joshua S (2015) New public management and developmental state: Revisiting the institutional imperatives in Nigeria. Mediterranean Journal of Social Science 6 (3):58-66.

Kurtz DL \& Boone LE (2011) Contemporary Business 14th Edition. United States of America: John Wiley \& Sons, Inc.

Lan MT (2016) Public management and strategic management in Vietnam state-owned enterprises (SOEs). International Business Research Vietnam University of Commerce 9 (4):58-65.

Lumentut L, Rifai B, Aburaera S, \& Sumardi J (2017) The transparency principle in realize good corporate governance: Limited company. IOSR Journal of Humanities and Social Science $22(4): 50-57$.

Miles MB, Huberman AM, \& Saldana J (2014) Qualitative Data Analysis: A Methods Book 3rd Edition. Thousand Oaks, CA: Sage Publication.

Nhema AG (2015) Privatisation of public enterprises in developing countries: An overview. International Journal of Humanities and Social Science 5 (9):247-256.

Osborne D \& Plastrik P (2000) Memangkas Birokrasi (Lima Strategi Menuju Pemerintahan Wirausaha). Jakarta: Penerbit PPM.

Osborne SC (2006) The new public governance. Public Management Review 8 (3):377-387.

Osborne D \& Gaebler T (1999) Mewirausahakan Birokrasi Mentransformasi Semangat Wirausaha ke dalam Sektor Publik. Jakarta: PT Pustaka Binaman Pressindo.

Philip DD \& Daganda AT (2013) New public management and public sector administration in Nigeria. International Affairs and Global Strategy 14:9-15.

Pollit C (2007) The new public management: An overview of its current status. Journal of Public Management 8:110-115.

Sugito T, Sulaiman AI, \& Sabiq A (2017) The role of society and village government in empowering potential and former migrant workers. International Journal of Management and Applied Science 3 (2):13-15.

Stoker G (2006) Public value management a new narrative for networked governance?. American Review of Public Administration Published by Sage Publications 36 (1):41-57.

Subandi E (2016) The role of village chief in improving public participation for rural development (a case study at the village office of Margorejo District of Parengan Tuban Regency). Imperial Journal of Interdisciplinary Research (IJIR) 2 (5):193-198. 
Suriadi A, Rudjiman, Mahalli K, Achmad N, \& Muda I (2015) The applicative model of the villageowned enterprises (BUMDes) development in North Sumatera. Global Journal of Arts, Humanities and Social Sciences 3 (12):48-62.

Vantha K (2016) The new public management: Concept analysis and implications in the context of cambodian public service reform. International Journal of Public and Private Management, 2 (2):33-47.

Wilson K, Hannington S, \& Stephen M (2015) The role of community participation in planning processes of emerging urban centres. A study of paidha town in Northern Uganda. International Refereed Journal of Engineering and Science (IRJES) 4 (6):61-71. 